\title{
UN Peacekeeping in a Multipolar World Order: Norms, Role Expectations, and Leadership
}

\author{
Adriana Erthal Abdenur
}

\section{INTRODUCTION}

Shortly after Donald Trump was elected President, in November 2016, US government representatives announced that the US would significantly cut back on its financial contributions to the UN. In addition, the new administration pledged to pressure the UN to reduce its peacekeeping budget, for instance by closing a number of missions and undertaking a comprehensive review of peace operations (Lynch 2017). The announcements provoked alarm due not only to the financial and political implications, but also because of the repercussions to the internal politics of the US. In mid-2017, this foreshadowing became concrete when, under pressure from the US, the General Assembly agreed to significant cuts to the peacekeeping budget. American Ambassador Nikki Haley gloated that the US, in seeking "more bang for its buck," was trimming the "fat around the edges" of the UN security budget (Haynes 2017).

\footnotetext{
A. E. Abdenur $(\square)$

Instituto Igarapé, Rio de Janeiro, Brazil

(C) The Author(s) 2019

C. de Coning and M. Peter (eds.), United Nations

Peace Operations in a Changing Global Order, https://doi.org/10.1007/978-3-319-99106-1_3
} 
Although the cuts remained below what the Trump administration had sought, the reduction in both resources and US interest have created more pressure to scrutinise and improve peacekeeping effectiveness.

Yet the perception of tectonic shifts within the world's most important global governance body predated these budget cuts and even Trump's election. US hegemonic power has not only been cast into doubt, but in fact has been actively contested, especially by "rising powers" whose leaders decry the injustices and resulting challenges of key mechanisms - including the asymmetries built into UN peace operations. Moreover, the US is not the only Western power in apparent decline. The European Union (EU) has delved into an identity crisis since the June 2016 Brexit referendum, and other member states have seen the rise of Euroscepticism. Against this backdrop, Trump's cavalier detachment from UN security issues has added further urgency for structural changes in global governance.

The UN itself has long acknowledged the need to revamp its peacekeeping norms and practices. The UN High-Level Independent Panel on Peace Operations (HIPPO), launched in 2014 by Secretary-General Ban $\mathrm{Ki}-\mathrm{moon}$, deepened this discussion and produced concrete recommendation for enhancing effectiveness. Although the panel report concentrated on the nuts and bolts (and norms) of UN peacekeeping rather than the geopolitical underpinnings of those challenges, the effort was undertaken within broader debates about systemic change in global governance. As the first major external review of UN peacekeeping since the Report of the Panel on UN Peace Operations chaired by Lakhdar Brahimi in 2000 (UN 2000), the HIPPO (henceforth the Panel) opened up a window of opportunity to reflect not only upon the reforms implemented over the past fifteen years, but also upon the unmet and emerging demands. Change in top leadership seemed to further expand this perceived window. At the end of 2016, António Guterres became UN Secretary-General. Guterres has held up the banner of conflict prevention since his campaign, also indicating that more effort would be placed on political strategies to avoid and resolve conflict. Discussion of conflict prevention, however, remains thus far rather abstract, disperse, and all-encompassing, especially since Guterres has had to devote considerable energy to addressing the tensions and uncertainties triggered by the Trump administration.

These tectonic shifts, emerging uncertainties, and shifting leaderships are not the only source of change in the peacekeeping field. Scholars 
of armed conflict have long noted structural changes in the nature of conflicts, such as the proliferation of so-called "new" or "hybrid" wars - the growing incidence of intra-state violence associated with fundamentalist non-state groups, ethno-political tensions, rebel separatism, armed resistance to authoritarian regimes, and non-state criminal groups, all of which are often associated with new dynamics in the conduct of war as well as increasingly fragmented battlefields. In the postCold War, as Kaldor (2013) has noted, there is increasingly a "blurring of war and crime." Combined, these factors point to serious challenges ahead for a peacekeeping system that originated in the rigid and predominantly state-centric order of the Cold War and that remains generally illprepared to deal with the particularities of post-Clausewitzean conflicts.

Given this changing context, what are the main implications of the multipolarisation of the world order for UN peacekeeping? This chapter explores two interrelated dimensions of security global governance and conflict management: norms-setting and role expectations. New uncertainties about leadership and emerging resources on constraints prompt changing expectations of, and concern about, rising powers. China, in particular, emerges as a potential leader, but Beijing's willingness and ability to quickly expand its influence over UN security architecture should not be taken for granted.

The chapter is structured as follows. The first part briefly explores the concept of multipolarity and the new (if highly variable) salience of rising powers in international affairs. Next, the paper looks at how these phenomena have affected UN peacekeeping with reference to normative debates and role expectations. The conclusion highlights some of the key takeaway points and notes directions for future research.

\section{Multipolarisation of the World Order}

Working to decipher the interactions among world leaders in the 2017 G-20 meeting, held in Hamburg, political scientists and pundits grasped for new expressions to describe the apparent end of the US-dominated world order; one recurring term was "G-Zero world," where no single country or bloc is able to shape or direct global events. "The era of the cacophony is upon us," proclaimed the Economist (2017). Chaos became the leitmotif within the mainstream media coverage of the event.

Major summits like the G-20 underscored a trend that has been hotly debated in international relations discussions, both theoretical and 
empirical. Some international relations scholars argue that the system is already undergoing a transition towards a more multipolar system, ${ }^{1}$ with new engines of economic growth and political agency challenging the presumed hegemony of global powers, especially the United States. Indeed, more than in any other period of modern history, rising powers have become more vocal in their revisionist stances and increasingly work together in pressing for change, including at the UN (Acharya 2014). In 2009, for instance, Brazilian President Luiz Inácio Lula da Silva titled his opening speech at the UN General Assembly "The Multipolar World and the Revitalisation of the United Nations" (da Silva 2009).

Here the expression "rising powers" refers to states that exert a considerable degree of influence within their respective regions, and whose leaderships nurture broader ambitions at a global level yet face constraints on their ability to project both soft and hard power. In some cases, this ambition to expand power is partially motivated by a desire to recover a perceived lost status of global power, as in the cases of Russia and China. It is also rooted in the idea that there are alternatives to "Western" ideals and principles. As a result, while China, India, and Brazil, among others, remained open to cooperation with Western powers, they also found themselves at odds with certain established governance systems and norms. In general, they also became more sceptical of the Western strategy of incorporating the rest of the world into a value system presented as being universal. Under Putin, for instance, Russia-particularly since the 2014 annexation of Crimea-has steadfastly refused to "follow the West" (Lukin 2016).

In addition to contesting the status quo individually, these countries began to pool together their voices and, to some extent, their resources in pressing for a more representative global governance system-one that would not only better reflect the current distribution of power, but that would also expand their own influence in international relations. The formation of the G20, in 1999, brought together major powers and rising ones and represented an attempt to expand the "inner circle" of global leadership (previously firmly entrenched in the G-7) while foment dialogue outside the confines of established institutions like the UN. The importance of these fora, however, have varied in the eyes of rising powers Their primary collective strategy has entailed loose,

\footnotetext{
${ }^{1}$ For an overview of the debate until the turn of the millennium, see Lynn-Jones (2008). For more recent discussions, see Haass (2008) and Laidi (2014).
} 
transregional groupings of rising powers - not only the BRICS, but also the India, Brazil, South Africa (IBSA) Dialogue Forum and the Shanghai Cooperation Organisation, where the absence of Western powers allows member states to promote a contestation discourse far more openly.

These coalitions vary in both composition and agenda, but they have adopted openly revisionist (if often rather vague) official discourses. Although these coalitions bring together economically, politically, and geographically diverse countries, they share the perception of having stood outside the international core group of the West (and Japan) that has dominated the world system for the past decades (de Carvalho and de Coning 2013; Wiharta et al. 2012). In 2013, at the annual BRICS Summit, Russian President Vladimir Putin called the BRICS coalition formed by Brazil, Russia, India, China, and South Africa "a key element of the emerging multipolar world" (RT 2013).

The shift towards a more multipolar order has been highly variable, both across different arenas of international affairs and over time. In international security, the multipolarisation process has been more incremental and uncertain. Here the status quo in international security has rested on two pillars. The first pillar is the continuing military supremacy of the United States: despite the recent expansion of Chinese military power, US hard power outpaces that of any other state by a wide margin, along all key measures. The second pillar is the failure to reform the UN Security Council (UNSC), which means that major decisions regarding the use of force are still taken by the Permanent Five (P5).

Despite these elements of continuity, there are growing challenges to Western dominance. The number of states possessing nuclear weapons has expanded, especially among non-Western states. Although US hard power exceeds that of other states by a wide margin, the robustness of US military power is cast into doubt as the United States finds itself embroiled in complex conflicts in the Middle East, North Africa, and Central Asia-as well as rising inter-state tensions in the Pacific. In addition, attempts by previous administrations to expand US soft power through mega-agreements like the Trans-Pacific Partnership (TPP) have been reversed by the Trump administration and opened up windows of opportunity that China and Russia, in particular, have been quick to seize, including through multilateral initiatives like the Belt and Road Initiative.

Far from uniform, multipolarisation of the world order has also varied over time, even within the relatively short span of time since the 
turn of the millennium. For some rising powers, the bravado exhibited by rising power leaderships in the 2000s has given way to a more discreet participation in world affairs. This is especially the case for states undergoing significant economic slowdown or political turmoil, as in the cases of Brazil and South Africa. Others, such as Russia and Turkey, have become more combative of perceived Western pressures due to a combination of domestic politics and geopolitical interests. While the word "chaos" may overestimate the fragmentation of the current world order, rising powers certainly find more space in which to manoeuvre, certainly within their own regions and, in some cases, even beyond them. Although it remains to be seen what type of scenario will emerge out of these changes in world leadership and realignments among rising powers, the reconfiguration of the system has deep repercussions for the UN security architecture, including its peace operations.

\section{Impact of Multipolarisation on UN Peace Operations}

Multipolarisation has already generated new demands and changing expectations about UN peacekeeping. From the perspective of rising powers, although they have long been contributors (especially of troops and police) to UN peacekeeping operations, a systemic transition offers a chance to boost their normative influence as well as operational role in international security and governance. UN peacekeeping has thus become part of a broader "rising power strategy" that combines intensifying engagement even as those states remain dissatisfied with the concentration of decision-making at the hands of Western states. However, not all rising powers are alike; those that are part of the P5 states (China and Russia) assume a more pivotal role than non-P5 rising powers. Broadly put, however, the resulting tension between engagement and contestation of the UN security architecture becomes apparent across both norms-setting and roles expectations.

\section{Norms-Setting}

UN peace operations are characterised by some glaring asymmetries in terms of which countries mandate, fund, and implement peacekeepingan imbalance that has sharpened since the 1990s, when Western countries decreased uniformed personnel from UN operations and as UN peacekeeping underwent a dramatic surge in the 2000s (Bellamy and 
Williams 2013). Industrialised states and P5 member states, bolstered by financial resources, political leadership, and accumulated institutional learning, lead the process of setting rules but do not all contribute significant numbers of troops and police to peace operations. There have been some efforts to redress this asymmetry. The "New Horizon" initiative, launched in 2009 by the UN Department of Peacekeeping Operations (DPKO) and Field Support (DFS), sought to expand the pool of Troop Contributing Countries (TCCs) and Police Contributing Countries (PCCs). The 2015 report issued by the HIPPO addresses the normative imbalances in peacekeeping timidly and indirectly, through general recommendations on partnerships and effectiveness yet without addressing the geopolitical underpinnings of this divide (UN 2015).

Thus far, however, this picture has not been reverted. In 2016, the top providers of assessed contributions to UN peacekeeping operations were the United States (28.57\%), China (10.29\%), Japan (9.68\%), Germany (6.39\%), France (6.31\%), the United Kingdom (5.80\%), Russia (4.01\%), Italy (3.75\%), Canada (2.92\%), and Spain (2.44\%) (UN 2017a). In other words, aside from China and Russia (both P5 countries and states that are sometimes classified as rising powers), all top contributors are Western states and Japan.

Developing countries, on the other hand, provide the bulk of military and police staff, who are deployed to the field often without proper equipment and training (especially when compared with their Western counterparts) and are exposed to direct risks and suffer the majority of casualties. In 2016, the top peacekeeper contributors (military and police combined) were all African and Asian: Ethiopia, India, Pakistan, Bangladesh, Rwanda, Nepal, Senegal, Burkina Faso, Ghana, and Egypt (UN 2016a). These states have little voice in the formulation and adoption of peacekeeping mandates. China-the top contributor among the members of the UNSC since 2004-has moved up the ranks consistently and will probably continue to do so, but it has not yet broken into the top ten (China was listed as number 12 in early 2017).

This uneven distribution of decision-making power and risk can directly influence the operations of a UN peacekeeping mission. For instance, Western powers can override the authority of commanding officers of peacekeeping forces, including where geopolitical interests are at stake (Khan 2006). The Indian representative to the UN has recently complained about the lack of consultation between the Council and Member States contributing troops to peacekeeping missions, adding 
that "the current structure and working methods of the 15 -member body were divorced from reality and represented a bygone era ..." and hoped that "a cataclysmic crisis would not be needed to foster such a fundamental change" (UN 2016b).

The imbalance also appears increasingly sharp in the changing division of labour between the UN and the African Union, as well as African Regional Economic Communities (RECs). Although African states and organisations stress the importance of local and regional agency in dealing with conflicts around the continent-to the extent permitted by its evolving capabilities - these partnerships face significant coordination challenges in terms of strategic, operational, and funding issues. Some African state complain that particularly the Security Council does not adequately take into consideration the region's views (Williams and Boutellis 2014). The asymmetries built into UN peace operationssome of which UN officials have referred to as "peacekeeping apartheid" - thus undermine both the legitimacy and effectiveness of peace operations.

These asymmetries are a direct consequence not only of disparities in the ability to make financial contributions, but also of the anachronistic way in which the UN still reflects the distribution of power at the end of World War II. ${ }^{3}$ Non-P5 rising powers have been more vocal about contesting global governance, including norms of peacekeeping, and are bound to continue to challenge them in two ways. First, rising powers seek to influence global governance mechanisms and to participate more directly in rules-making (rather than to be mere "rules-takers") in international security. As the Indonesian ambassador to the UN spelled out it in a 2016 Security Council debate, "Responsibility should be shared by giving emerging powers responsibilities commensurate to their respective capacity and competence to contribute to regional and global peace." (UN 2016c)

As such, rising powers have been critical of the power structures, both formal and informal, that underpin decision-making. Second, they contest more specific elements of the normative framework, including

\footnotetext{
${ }^{2}$ The phrase was used by Jean-Marie Guéhenno (2005), then Under-Secretary-General for Peacekeeping Operations, in a statement made to the Challenges Project on 2 March 2005 in London. See also Sidhu (2007).

${ }^{3}$ The only significant changes have been the replacement of Taiwan by the PRC and that of the Soviet Union by Russia.
} 
aspects of peacekeeping. For instance, many such countries have contested the Responsibility to Protect (R2P) norm and, more recently, the intersection between peacekeeping and anti-terrorism initiatives. Rising powers, in other words, want a greater say in deciding under what circumstances to undertake such operations, when to allow the use of force, and what the rules of engagement should be. This helps to explain why reform of the UNSC is such a central element in these countries' multilateral agendas.

Three trends can be discerned in non-P5 rising powers' recent participation in normative debates about UN peacekeeping. First, reflecting their aspirations to influence conceptual developments more closely, these states have stressed that peacekeeping operations should only take place with the permission of, and/or in partnership with, the UN. While this may remain true, with multipolarisation, rising powers may find more manoeuvre space for pursuing their regional ambitions, as well as deepening rivalries in areas where regional cooperation fails to take off or is undertaken in a lopsided manner.

For instance, regional dynamics in Eurasia have already begun to change dramatically not only due to the rise of China, but also due to the implementation of the Beijing-led Belt and Road Initiative. Although it remains largely a vision rather than a concrete project, the platform has already begun to change geopolitical and geo-economic relations between major regional players in Asia, promoting new configurations in cooperation but also potentially triggering new tensions in an area where rising powers have already resisted the presence of the UN security mechanisms (The Indian government, for instance, has called for an end to the UN Military Observer Group in India and Pakistan (UNMOGIP), which supervises the ceasefire line between the two countries). In June 2017, for instance, just as India grew more resistant to participating in the OBOR, India and China experienced another border flare-up when Indian troops halted a Chinese road-building project in the Himalayas (Barry and Huang 2017). Multipolarisation of the world order may heighten the regional geopolitical concerns and interests of some rising powers, hence weakening the position of the UN as the leading conflict management actor.

Second, rising powers have upheld the principle of respect for national sovereignty, for instance questioning the Responsibility to Protect (R2P) on the grounds that it can lead to violations of national sovereignty, that the norm is invoked in a highly selective manner 
that serves narrow Western interests, and that it has tended to lead to (at best) highly uncertain outcomes (Laskaris and Kreutz 2015). This scepticism was in full view when the BRICS countries criticised the UNSC Resolution 1973 in 2011, which permitted the establishment of a no-fly zone over Libya. The resulting intervention was presented by critics as an abuse of the UN mandate; as de Carvalho and de Coning put it, "The representatives of the BRICS in the Security Council argued that they will not make the mistake again of trusting the West with the authority to undertake 'limited action,' which can then be used as a justification to launch an intervention that amounts to regime change" (de Carvalho and de Coning 2013). In a Security Council meeting in February 2016, the Egyptian ambassador stressed that "the Council must remain objective and it must adopt the 'natural path' to address issues according to the Charter, giving priority to peaceful means of conflict resolution and respecting the sovereignty of States" (UN 2016c).

The Russian annexation of Crimea and, more recently, its role in the Syrian conflict have cast doubt on Russia's commitment to the principle of non-intervention, at least as understood from a Western perspective. Although China has historically adopted a cautious stance in UN security discussions (most notably by exercising its veto power very infrequently), its economic and defence interests have rapidly globalised, not only in Asia but increasingly in Africa and Latin America. Some analysts argue that China is beginning to be flexible in its stance on non-interference in the internal affairs of other states, for instance by offering to carry out some mediation of international conflicts, by carrying out large-scale evacuations of Chinese citizens when conflict breaks out, or even through its increasingly bold peacekeeping engagement, for example deploying peacekeepers in South Sudan starting 2017 (The State Council of the People's Republic of China 2017). Within the UNSC, however, China has generally remained more engaged in tempering the use of force than in proposing new norms for peacekeeping altogether (International Crisis Group 2009, pp. 2-3).

Third, rising powers have often opposed what they consider to be the sometimes premature mobilisation of peacekeepers to address outbreaks of conflict, arguing that instances of escalating violence must be analysed on a case-by-case basis. The trend towards more robust peacekeeping mandates notwithstanding, in their view, UN mechanisms such as economic sanctions and especially the use of military force is to be used only as a last resort, when peaceful means to conflict resolution have been 
exhausted. In this perspective, despite the UN Charter's emphasis on early warning, preventive diplomacy, good offices, and mediation, the UN sometimes exhibits a knee-jerk reaction in deploying peacekeepers.

Within a more multipolar world order, there may be room for further convergence between rising powers and Western states as scepticism of nation- and state-building, based on the assumption that societies can be (re)engineered through a top-down approach to "fixing" "failed states," also spreads in Western countries and institutions. As more people recognise that, rather than invariably benevolent and objective, the liberal peace paradigm of democracy and market economy can lead to unexpected results, including exacerbated instability (Zambakari 2017), rising powers are bound to feel less isolated in their positions at the UN. This convergence, however, will depend heavily on Secretary General Guterres' ability to push forward an agenda for reform of peace operations that not only ensures the implementation of the HIPPO recommendations but, in fact, goes well beyond those.

Rising powers have at times been accused of acting more as norms-blockers - setting up obstacles to the implementation of proposed norms - than as norms-entrepreneurs who bring to the table new ideas and invest politically so as to back up innovative proposals (Abdenur 2016). Brazil's proposal of the Responsibility while Protecting (RwP) concept was an important contribution to the ongoing debate over the use of force and the protection of civilians, but the proposal was hampered in part by a lack of political commitment to advancing the discussion (Almeida 2013). South Africa's introduction of the concept of non-indifference has been influential in other states' foreign policies (including that of Brazil's) and within the discourse of the African Union, but the concept has remained rather vague and is applied in a highly uneven fashion. In a context of declining US leadership within the UN, rising powers (both those within and outside the Security Council) may find more space for proposing normative innovation, but gathering the political momentum required to enact change will require creating a critical mass around new proposals.

\section{Role Expectations}

Most discussions around role expectations and UN peacekeeping revolve around missions' ability to carry out their mandates, or the mandates themselves. Here I refer more specifically to expectations on the 
part of the international community, especially at the UN and partner organisations, regarding the official and unofficial division of labour that emerges in defining, structuring, and implementing peacekeeping. With multipolarisation, expectations have begun to shift, especially around "pivotal states"-countries that could help fill the space left behind by a declining US leadership.

This idea was reinforced during a June 2017 news conference in New York, when Secretary-General Guterres warned that an American retreat from the world meant serious risks: "When someone leaves space, that space is always occupied by others" (UN 2017b). In May, during a talk at New York University, Guterres had given concrete examples: "It's not only the Russias and the Chinas that are occupying the ground; if you look at Saudi Arabia, Turkey, Iran, the regional powers in many parts of the world-when the big powers leave some space, they will occupy it" (Nichols 2017). In addition to voicing concerns about the Trump administration's decision to withdraw from the Paris climate agreement, new US migration policies, and deep cuts to the UN budget, Guterres was raising the issue of what leadership at the UN will look like in a multipolar world order.

Many of these changing expectations concern the responsibilities that different sets of actors should assume within a world order in which conflict-related demands seem to grow more complex even as available resources shrink. As suggested by Guterres' comments, leadership roles are up for grabs, with expectations of the European Union (EU) stepping in dashed by the uncertainties and identity crisis unleashed by the UK Brexit referendum in 2016. The 2017 G-20 meeting, held in Hamburg, was widely interpreted as reflecting a divided world leadership and signalling a rapid decline in expectations of the US. Many G20 countries, including traditional partners like France and Canada, have opted to circumvent the Trump administration rather than bandwagon with the new foreign policy decisions implemented by the US; at the same time, Russia and Turkey have stepped up their defiant tones. In as much as UN politics mirror broad shifts in geopolitics, these shifting alignments generate further uncertainty for UN peacekeeping.

Another set of expectations subject to change involves the North/ South split in UN peacekeeping decision-making and implementation. Budget cuts means there will be even fewer resources with which to level the playing field in terms of equipment, training, intelligence, and coordination, increasing risks to the TCCs and PCCs. These problems are 
of particular concern in robust peacekeeping operations like the United Nations Organization Stabilization Mission in the Democratic Republic of Congo (MONUSCO) and the United Nations Multidimensional Integrated Stabilization Mission in Mali (MINUSMA), in which troops, police, and other personnel are subject to complex conflicts. In Mali, for instance, MINUSMA peacekeepers are increasingly targeted by improvised explosive devices and car bombs; a total of 146 peacekeepers there have been killed since 2013 (UN 2017c). Although including counterterrorism operations in peacekeeping mandates is controversial, as the commander of the MINUSMA intelligence unit has put it, those risks are unlikely to abate in peacekeeping settings: "This is not the end of this type of mission. It's the beginning" (Sieff 2017). Coupled with growing scepticism of UN peacekeeping effectiveness, these risks, as well as more traditional ones from state and non-state armed groups, are likely to magnify the perception of unfair burdens assumed by Global South contributors to UN peacekeeping.

Regarding rising powers like the BRICS states, there are increasing expectations (by global powers as well as lower-income states) that they will expand and diversify their contributions to international security. This applies to both the Security Council permanent seat holders and to the other three countries, but unevenly. Among the P5, China in particular is called upon to expand its contributions, not only in terms of financing and personnel deployment, but also with respect to defining mandates and the appropriateness of the use of force. Even before Guterres was selected as Secretary General, China had been diversifying and intensifying its commitments to UN peacekeeping, contributing thousands more troops, making major investments in peacekeeper training, and placing 8000 troops at the disposal of a UN standby force. By 2016, China was the second-largest contributor to the UN peacekeeping budget and deployed more peacekeepers than the four other P5 countries combined (Lynch 2017).

China's increased interest in, and engagement with, UN peacekeepingespecially at a time when the Trump administration voiced open disdain for the United Nations-triggered alarm bells among some Western specialists. In October 2016, a Foreign Policy article warned that China had set "its sights on the United Nations' top peacekeeping job," adding that Chinese leadership in this area would have serious normative implications, especially for human rights. The article cited a senior UN official stating Russia was also "making a play for DPA" and an expert saying that 
"We're seeing the first phase of a Chinese bid to, firstly, assert itself over UN peacekeeping and, secondly, to rewrite the rules of UN peacekeeping" (Lynch 2017). The Diplomat asked, "Is the UN About to Enter the Era of Chinese and Russian Dominance?" (Witthoeft 2016). New York-based think tanks viewed the bid as a potential turning point; the International Peace Institute (IPI) opined that "China heading up the United Nations Department for Peacekeeping Operations (DPKO) would represent one of its most significant overtures toward leading, rather than merely participating in, the post-1945 global order" (Bowen 2016). Although Guterres ended up appointing France's Jean-Pierre Lacroix as Under-Secretary for Peacekeeping Operations, the breathless tone of the debate about expanding non-Western influence at the $\mathrm{UN}$ - especially the concerns over an ambitious China and a revisionist Russia-reflects the changing expectations for rising powers in UN peacekeeping.

While the recent increases in China's contributions to UN peacekeeping signal a clear uptick in its commitment to peace operations, it is not yet clear whether Beijing would be willing to assume a clear-cut leading role-or, even if it is, whether it is capable of doing so in the near future. Xi Jinping is attempting to lead a difficult (albeit not insurmountable) structural transition, and the relative deceleration of the Chinese economy-down from double-digit rates to a "mere" 6.5\% annual GDP growth per year-translates into fewer resources. Abroad, aside from the UN, China has many other areas of diplomacy and cooperation it is trying to build up, both regionally and globally. Alongside China's engagement with the UN, its multilateral diplomacy (and its engagement with international security) also encompasses a variety of non-UN initiatives, including emerging regional or trans-regional cooperation configurations such as the two-pronged OBOR, the Shanghai Cooperation Organization, and the new financial institutions it has helped to launch, especially the Asian Infrastructure Investment Bank (AIIB) and the BRICS New Development Bank (NDB). In addition, China deals with a large number of domestic security issues, including separatist groups, as well as territorial disputes and reawakened historical rivalries in the South China Sea and recurring instability in the Korean peninsula. Chinese scholars have warned that, even within the context of a rapidly changing world order and the emergence of new opportunities, "China mustn't spread too thin" (Yinhong 2016).

Thus far, even as China openly competes with the US for power, leading both countries to reappraise their positions vis-à-vis one another 
as well as in global governance, Beijing has generally opted for a cautious projection rather than brash power-grabbing. Deng Xiaoping's exhortation to "keep a low profile, never take the lead, and make a difference" may have been toned down, but it has not been altogether discarded. ${ }^{4}$ A China-dominated UN peacekeeping field is possible, but unlikely to materialise in a just a few years.

To expand global peacekeeping engagement, the three rising power aspirants to a permanent seat at the Security Council-Brazil, India, and South Africa-have been called upon to assume greater responsibilities both within and beyond their immediate regions. The rationale is that, if these countries aspire to global power status, for instance as reflected in their bids for a permanent seat at the UNSC, then they should demonstrate deeper long-term commitment (political, financial, and otherwise) to hands-on engagement in UN peace operations, both at the normative and at the operational levels. However, particularly during economic downturns, these states resist committing further resources by invoking their status as developing countries, with important challenges to tackle internally that constrain their capacity to contribute (particularly financially) to UN peacekeeping. At the time of this writing, this is particularly true of Brazil and South Africa, both of which have experienced a combination of economic deceleration and political turmoil at home-in both cases, fuelled by allegations of extensive corruption. Just how "pivotal" these rising powers will be in a multipolar order will depend not only on their ability to restore stability and inclusive growth at home, but also in their capacity to take advantage of the rapidly changing international order.

Finally, multipolarisation also changes expectations regarding the role of regional organisations. The UN has retained primacy in peacekeeping, handling the largest number of peacekeeping operations (including robust missions) and serving as the main normative platform for debating and discussing when and how peacekeeping should be carried out. Nonetheless, in some places, regional organisations have assumed increasing protagonism, not only due to the limits of UN capacity but also because of the growing belief in the legitimacy and efficacy of more regional, sub-regional, or even localised solutions.

Because the bulk of peacekeeping takes place in Africa-it is estimated that $87 \%$ of uniformed UN personnel are deployed around the

${ }^{4}$ For more on this debate, see People's Daily (2012). 
continent - this growing complexity is particularly relevant to the region (de Carvalho 2015). As de Coning explains in this volume, the AU's African Peace and Security Architecture (APSA) has expanded considerably in the past decade. Recent innovations, such as a mediation unit and gender-specific policies, have lent momentum to some areas. However, the organisation's capacity is still highly uneven, with considerable weaknesses due to financing and capabilities. As multipolarisation accelerates, so do pressures for the AU and other regional organisations to take on an even bigger role in tackling conflicts within its geographic space. In addition, as regional powers like Egypt, Nigeria, Ethiopia, and South Africa find more room for manoeuvring within a multipolar context, geopolitics will continue to shape AU politics as those countries jockey for influence at a regional level.

\section{Conclusion}

The multipolarisation of the world order is well under way. Some of the notable changes in leadership and alignments observed over the past decade include the emergence of new economic growth nodes, more vocal contestation of the current global governance system by rising powers, and emerging "parallel" institutions of the Global South. Since 2016 especially, these trends have dovetailed more clearly with the decline of Western powers, especially the retraction of US power under Trump and the identity crisis besetting the European Union since the Brexit vote. Yet some rising powers are bound to play a more pivotal role than others.

The shift towards a multipolar configuration has significant implications for UN peacekeeping, and some of the effects are already becoming apparent. At a political level, the perceived leadership vacuum creates pressure for new sources of leadership in global governance, and it raises concern among some circles with the possibility of non-Western states, namely China, occupying this space, with important normative repercussions. While China has shown growing interest in assuming a more proactive role at the UN, taking up leadership will require concerted effort, investment of resources and diplomacy, and time.

Russia stands to gain influence, but will likely retain its predominantly legalistic views at the UN, including with respect to peacekeeping. Unlike China, it has no intentions of making a leap in contributions so as to expand influence on peace operations from outside the UNSC. Its military attention is more focused on countering NATO in Eastern 
Europe and in maintaining its footholds in Central Asia and the Middle east.

The role of other rising powers is more variable. Countries that experience considerable turbulence at home, Brazil and South Africa, may lack the resources of the pivotal states, but their long tradition of multilateral diplomacy will allow them to retain relevance in a multipolar world, including at the regional level. Rising powers that are directly embroiled in geopolitical hotspots, such as Turkey and Iran, may assume increasingly contestatory stances, at least with respect to their immediate vicinities.

At an operational level, the impending budget cuts provoked by US pressure lead to the closing of a number of missions and are bound to reinforce some of the asymmetries seen in the field. Although other Western states have begun signalling that they will not bandwagon with the US on major foreign policy decisions, the Trump administration's dismissive attitude towards the UN may promote a more hands-off approach to conflict management on the part of longstanding allies such as Canada, even if they diverge on other issues, such as the Paris climate agreement.

Multipolarity increases uncertainty and provokes realignments, but it is not equivalent to chaos. New nodes of decision-making emerge and upend normative engines of previous eras. At the same time, multipolarisation is not uniform or unidirectional; it may web and flow and manifest itself differently in different areas and spaces. Just as the fortunes of rising powers are subject to oscillations and even, in some cases, reversals, so is the decline of Western powers. It remains to be seen whether the world is experiencing a Tump Era or merely a Trump Interregnum, but analysis over time shows that the policies implemented by the US governments in 2017 are not the only driver of systemic change. This means that UN peacekeeping will undergo geopolitical pressures and changes not foreseen in organisational initiatives such as the HIPPO process.

Further research on the impact of multipolarisation on UN peacekeeping should thus ratchet down the level of analysis to look more specifically at how macro-level changes in inter-state and intra-state dynamics create new challenges for the UN architecture. Secondly, future research should investigate the ways that emerging regional cooperation arrangements like OBOR affect conflict prevention and management, whether within the realm of peacekeeping or in parallel to it. Finally, special attention should be paid to how multipolarisation 
affects the behaviour, choices, and expectations of other member states, whether individually or through groupings like the G7+.

\section{REFERENCES}

Abdenur, Adriana Erthal. 2016. Rising Powers and International Security: The BRICS and the Syrian Conflict. Rising Powers Quarterly l (1): 109-133.

Acharya, Amitav. 2014. The End of the American World Order. London: Polity.

Almeida, Paula Wojcikiewicz. 2013. From Non-Indifference to Responsibility while Protecting: Brazil's Diplomacy and the Search for Global Norms. Occasional Papers No. 138, South African Institute of International Affairs, Johannesburg.

Barry, Ellen, and Yufan Huang. 2017. With Modi in Washington, China and India 'Jostle' on Their Border. New York Times, June 27.

Bellamy, Alex J., and Paul D. Williams. 2013. Introduction: The Politics and Challenges of Providing Peacekeepers. In Providing Peacekeepers: The Politics, Challenges, and Future of United Nations Peacekeeping, ed. Alex J. Bellamy and Paul D. Williams. Oxford: Oxford University Press.

Bowen, James. 2016. Peacekeeping with Chinese Characteristics? October 20. New York: IPI Global Observatory.

da Silva, Lula. 2009. O mundo multipolar e a revitalizacão da ONU, Opening Speech at the UN General Assembly, October 9. New York: United Nations.

de Carvalho, Benjamin, and Cedric de Coning. 2013. Rising Powers and the Future of Peacekeeping and Peacebuilding, November 14. Oslo: Norwegian Peacebuilding Resource Centre.

de Carvalho, Gustavo. 2015. What's the Future of UN Peacekeeping? World Economic Forum, February 26. https://www.weforum.org/agenda/2015/02/ whats-the-future-of-un-peacekeeping/. Accessed 10 Nov 2017.

Guéhenno, Jean-Marie. 2005. Statement by Jean-Marie Guéhenno UnderSecretary General for Peacekeeping Operations to the Challenges Project, March 2. http://www.un.org/en/peacekeeping/articles/article020305.htm. Accessed 10 Nov 2017.

Haass, Richard N. 2008. The Age of Nonpolarity: What Will Follow U.S. Dominance. Foreign Affairs 87 (3): 44-56.

Haynes, Suyin. 2017. Nikki Haley Praises Cuts to the UN's Peacekeeping Budget, Sparking Online Backlash. Time, June 28. http://time.com/4838459/nikki-haley-tweet-un-peacekeepers-reaction/. Accessed 9 Nov 2017.

International Crisis Group. 2009. China's Growing Role in UN Peacekeeping. Asia Report No. 166, April 17, International Crisis Group, Beijing, New York and Brussels.

Kaldor, Mary. 2013. In Defence of New Wars. Stability: International Journal of Security \& Development 2 (10): 1-16. 
Khan, Adil Hasan. 2006. Emerging Challenges in UN Peacekeeping Operations. New Delhi: Institute of Peace and Conflict Studies, article \# 1956, March 1.

Laidi, Z. 2014. Towards a Post-hegemonic World: The Multipolar Threat to the Multilateral Order. International Politics 51 (3): 350-365.

Laskaris, Stamatis, and Joakim Kreutz. 2015. Rising Powers and the Responsibility to Protect: Will the Norm Survive in the Age of BRICS? Global Affairs 1 (2): 149-158.

Lukin, Alexander. 2016. Russia in a Post-bipolar World. Survival 58 (1): 91-112.

Lynch, Colum. 2017. White House Seeks to Cut Billions in Funding for United Nations. Foreign Policy, March 13.

Lynn-Jones. 2008. Preface. In Primacy and Its Discontents: American Power and International Stability, ed. Michael E. Brown, Owen R. Coté, Sean M. LynnJones, and Steven E. Miller. Cambridge: MIT Press.

Nichols, Michelle. 2017. UN Chief Warns If US Pulls Back, Others Will Fill Leadership Role. Reuters, May 31. http://www.reuters.com/article/us-usatrump-un-idUSKBN18Q2MD. Accessed 10 Nov 2017.

People's Daily. 2012. Should China Continue to Keep a Low Profile Attitude? December 13. http://en.people.cn/90883/8057776.html. Accessed 10 Nov 2017.

RT. 2013. BRICS Key Element of Emerging Multipolar World-Putin. Russia Today, March 22.

Sidhu, Waheguru Pal Singh. 2007. Regional Groups and Alliances. In The Oxford Handbook on the United Nations, ed. Thomas Weiss and Sam Daws, 217-232. Oxford: Oxford University Press.

Sieff, Kevin. 2017. The World's Most Dangerous UN Mission. The Washington Post, February 17.

The Economist. 2017. Angela Merkel, the G-Zero Chancellor. The Economist, July 7.

The State Council of the People's Republic of China. 2017. Chinese Peacekeepers Depart for South Sudan, February 26. The State Council of the People's Republic of China. http://english.gov.cn/state_council/ministries/2017/02/26/content_281475578780906.htm. Accessed 10 Nov 2017.

United Nations. 2000. Report of the Panel on United Nations Peace Operations. New York: United Nations.

United Nations. 2015. Uniting our Strengths for Peace-Politics, Partnerships, and People: Report of the High-Level Independent Panel on United Nations Peace Operations. New York: United Nations.

United Nations. 2016a. Ranking of Military and Police Contributions to UN Operations. Monthly Report, August 31. http://www.un.org/en/peacekeeping/contributors/2016/aug16_2.pdf. Accessed 10 Nov 2017.

United Nations. 2016b. Speakers in Security Council Urge Balance Between UN Role in State Sovereignty, Human Rights Protection, But Differ Over 
Interpretation of Charter Principles. United Nations General Assembly meeting, February 15. https://www.un.org/press/en/2016/scl2241.doc.htm. Accessed 4 Dec 2017.

United Nations. 2016c. Speakers in Security Council Urge Balance Between UN Role in State Sovereignty, Human Rights Protection, but Differ Over Interpretation of Charter Principles. Security Council Meeting, 15 February 2016. https://www.un.org/press/en/2016/scl2241.doc.htm. Accessed 10 Nov 2017.

United Nations. 2017a. How We Are Funded. www.peacekeeping.un.org, https://peacekeeping.un.org/en/how-we-are-funded. Accessed 4 Dec 2017.

United Nations. 2017b. Press Conference by Secretary-General António Guterres at United Nations Headquarters. SG/SM/18580, June 20. https://www. un.org/press/en/2017/sgsml8580.doc.htm. Accessed 10 Nov 2017.

United Nations. 2017c. Fatalities Geographic Map. United Nations Peacekeeping. https://peacekeeping.un.org/en/fatalities-geographic-map. Accessed 4 Dec 2017.

Wiharta, Sharon, Neil Melvin, and Xenia Avezov. 2012. The New Geopolitics of Peace Operations: Mapping the Emerging Landscape. Stockholm: Stockholm International Peace Research Institute.

Williams, Paul D., and Arthur Boutellis. 2014. Partnership Peacekeeping: Challenges and Opportunities in the United Nations-African Union Relationship. African Affairs 113 (451): 254-278.

Witthoeft, Andrew. 2016. Is the UN About to Enter the Era of Chinese and Russian Dominance? The Diplomat, October 12.

Yinhong, Shi. 2016. Amid Western Uncertainties, China Mustn't Spread Too Thin. Global Times, October 26.

Zambakari, Christopher. 2017. Challenges of Liberal Peace and Statebuilding in Divided Societies. ACCORD Conflict Trends 2016/4, February 16. 
Open Access This chapter is licensed under the terms of the Creative Commons Attribution 4.0 International License (http://creativecommons.org/licenses/ by $/ 4.0 /$ ), which permits use, sharing, adaptation, distribution and reproduction in any medium or format, as long as you give appropriate credit to the original author(s) and the source, provide a link to the Creative Commons license and indicate if changes were made.

The images or other third party material in this chapter are included in the chapter's Creative Commons license, unless indicated otherwise in a credit line to the material. If material is not included in the chapter's Creative Commons license and your intended use is not permitted by statutory regulation or exceeds the permitted use, you will need to obtain permission directly from the copyright holder.

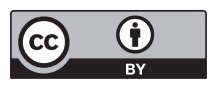

